\title{
The Atmospheric Environment
}





\section{The Atmospheric EnVironment EfFects of Human Activity}

Michael B. McElroy

Princeton University Press

Princeton and Oxford 
Copyright (C 2002 by Princeton University Press

Published by Princeton University Press, 41 William Street, Princeton,

New Jersey 08540

In the United Kingdom: Princeton University Press, 3 Market Place, Woodstock, Oxfordshire OX20 1SY

All Rights Reserved

Library of Congress Cataloging-in-Publication Data

McElroy, Michael B.

The atmospheric environment : effects of human activity / Michael B. McElroy. p. $\mathrm{cm}$.

Includes bibliographical references and index.

ISBN 0-691-00691-1 (acid-free paper)

1. Atmosphere. 2. Nature--Effect of human beings on. I. Title.

QC861.3 .M34 2002

551.51--dc21

2001032106

British Library Cataloging-in-Publication Data is available

This book has been composed in 10/12 Berkeley

Printed on acid-free paper. $\infty$

www.pup.princeton.edu

Printed in the United States of America

$\begin{array}{llllllllll}10 & 9 & 8 & 7 & 6 & 5 & 4 & 3 & 2 & 1\end{array}$ 


\section{For}

Stephen, Brenda, Lisa, Zoe, and Abby, and the future they represent 
